\title{
PRODUCTION OF POLYHYDROXYBUTERATE (PHB) FROM INDUSTERIAL WASTE
}

\author{
Gmal A Gabr ${ }^{1}$ and Nahla M. M. Hassan ${ }^{2}$ \\ ${ }^{1}$ Department of Pharmacology, Faculty of Pharmacy, Salman Bin Abdul-Aziz University, \\ KSA \\ ${ }^{1}$ College of Applied Medical Science, Salman Bin Abdul-Aziz University, KSA \\ ${ }^{2}$ Food Technology Research Institute, Agricultural Research Center, Giza, Egypt.
}

\begin{abstract}
Biodegradable polymers are of reasonable medical and agricultural applications nowadays. Samples from various natural environments in South Riyadh area, Saudi Arabia, were screened for microorganisms that are capable of producing poly (3-hydroxybutyrateco-4- hydroxybutyrate). A total of 50 isolates were collected and two out of those were identified as possible PHA producers based on Nile red staining methods. The isolate NG-2 obtained in this study was cultivated in MSM containing date palm syrup as inexpensive carbon source for economic production. Moreover, PHA was extracted from the NG-2 isolate and analyzed by IR followed by electron microscope to confirm the capability of producing PHB. Efforts have been paid to determine the optimal condition of the culture growth and its biodegradation activity. It was found that despite of the type of the polymercontaining media used, the optimum incubation temperature for the tested microorganism was $37^{\circ} \mathrm{C}$, while $\mathrm{pH}$ value of 7.2 resulted in the best growth pattern in date palm syrup at concentration of $8 \%$ containing media.

Our major goal is to develop biodegradable drug carriers as effective drug delivery systems that release particular nutrient or drug at a particular site. This biotechnology of biological delivery has a unique physiochemical and mechanical properties help in field of pharmaceutical and nutraceutical targeting. This sort of nanotechnology will appear in subsequent works.
\end{abstract}

Keywords: marine bacteria _ Polyhydroxyalkanoate _ Nile red _ PHA producer _

\section{INTRODUCTION}

Plastics has a lot of applications in our life and have demand increase each year. They are utilized in almost every manufacturing industry, ranging from automobiles to medicine. According to its chemical structure plastics has importance in industry, it can be manipulated in a wide range of shapes. The elasticity and strength of plastic make it easily be molded into different applicable shapes ranging from fibers to thin films (Madison and Huisman, 1999).

Most of plastics and synthetic polymers are produced from petrochemicals and because of its haz ards on human health and its damage effects on environment, there are growing studies concerning the use of biodegradable polymers as an ecologically useful alternative. The biopolymer are produced from renewable resources and do not depletion of the resources.

Among various biodegradable polymer materials, plastics are replaced by the polyhydroxy alkanoates (PHAs) because it has the same properties of petrochemical plastics. Moreover, it can be completely degradable and easily be used in different applications (Page, 1992). They are accumulates in numerous microorganisms under unbalanced growth 
conditions as a mechanism of storage excess carbon and energy (Ojumu et al., 2004 and Mahishi et al., 2003).

Many bacterial strains either Gram-negative or Gram-positive accumulate PHB and can grow on different types of growth media with different carbon and nitrogen sources. Among of these strains are Ralstonia eutropha, which represent the most promising microorganism used now for production of commercial PHB (Lee, 1996).

For commercialization of PHAs, tremendous efforts have been devoted to reduce the production cost by the development of better bacterial strains and more efficient fermentation recovery processes (Choi \& Lee, 1998 and Ahn et al., 2000).

From past decade, PHAs has attention from different scientific studies as metabolism, biochemistry, physiology and molecular genetics. Now the genetic studies cleared that the polyhydroxy alkonlate (PHAs) are produced from different variety of microorganisms and can be produced in a large scale production by using gene transformation.

PHA biopolymer has many advantages, they are biodegradable, insoluble in water, non-toxic, biocompatible, thermoplastic. These advantages make them unique substances suitable for different applications such as packaging industry, medicine, pharmacy, agriculture, food industry, and the production of paints (Christopher and Anthony 2012).

The quantity of the storage biopolymer inside bacterial microorganisms is affected by different environmental and physiological conditions. Incubation temperature, incubation time, hydrogen ion concentration, and the nutrients may enhance or stimulate PHAs production (Gulab et al., 2011).

The present study aimed to investigate the bacterial strains isolated from one of Saudi industrial area with the ability to accumulate PHAs as a unique storage material.

\section{MATERIALS AND METHODS}

\section{Isolation, screening and selection of PHA producing bacteria}

Bacterial strains were isolated from industrial waste water samples, industrial area, South Riyadh. The isolation procedure of all isolates was performed according to the method of Quillaguamán et al. (2004) as follows: $100 \mu \mathrm{L}$ of water sample was spread on solid $\mathrm{HM}$ medium, containing $(\mathrm{g} / \mathrm{L}): 30 \mathrm{NaCl} ; 0.25 \mathrm{MgSO}_{4} .7 \mathrm{H}_{2} \mathrm{O} ; 0.09 \mathrm{CaCl}_{2} ; 0.5 \mathrm{KCl} ; 0.06 \mathrm{NaBr} ; 5$ peptone; 10 yeast extract; 1 glucose; and 20 agar. The $\mathrm{pH}$ was adjusted to 7 and the plates were incubated at $35^{\circ} \mathrm{C}$ for $30 \mathrm{~h}$. The colonies produced were isolated by plating them again on fresh agar medium.

Bacterial isolates were grown again on a modified solid $\mathrm{HM}$ containing $(\mathrm{g} / \mathrm{L}): \mathrm{NaCl}$, $30 ; \mathrm{MgSO}_{4} .7 \mathrm{H}_{2} \mathrm{O}, 0.25 ; \mathrm{CaCl}_{2}, 0.09 ; \mathrm{KCl}, 0.5 ; \mathrm{NaBr}, 0.06 ; \mathrm{KH}_{2} \mathrm{PO}_{4}, 0.25$, yeast extract, 2; granulated agar, 20 and $\mathrm{pH}$ 7. The previous media supplemented with adding of $5 \%$ date palm syrup (Khalas) as inexpensive carbon source.

Nile red (Sigma) with final concentration of $0.5 \mu \mathrm{g}$ dye per $\mathrm{mL}$ of the medium was added. Plates were then exposed to ultraviolet light $(300 \mathrm{~nm})$ to monitor the accumulation of the PHA. The lighted plates were recorded as positive result.

\section{Factors affecting PHAs production}

More investigation was carried out on the NG-II isolate to study the culture conditions that affects production of PHA. Therefore, three different media as YT media 
containing (g/l) $16 \mathrm{~g}$ trypton, $10 \mathrm{~g}$ yeast extract and $10 \mathrm{~g} \mathrm{NaCl}$, the $\mathrm{pH}$ was adjusted to 7.0 (Hanahan, 1985), SG media containing 25\% $\mathrm{NaCl}(\mathrm{w} / \mathrm{v}), 2 \% \mathrm{MgSO}_{4} .7 \mathrm{H}_{2} \mathrm{O}(\mathrm{w} / \mathrm{v}), 0.2 \%$ $\mathrm{KCl}(\mathrm{w} / \mathrm{v}), 3 \%$ trisodium citrate $(\mathrm{w} / \mathrm{v}), 1 \%$ yeast extract $(\mathrm{w} / \mathrm{v})$, and $0.75 \%$ Casmino acids (w/v), the $\mathrm{pH}$ was adjusted to 7.0, and LB media containing (g/l) $10 \mathrm{~g} \mathrm{NaCl}, 10 \mathrm{~g}$ trypton and $5 \mathrm{~g}$ yeast extract were used with different cultivation conditions (Lee, 1996, Ramsay et al., 1990 and Kim et al., 1994). Moreover, incubation temperature, pH, various carbon sources were also tested, with respect to their PHA accumulation, in flasks that incubated on a shaker (200 rpm).

\section{Extraction of the PHA}

\section{Recovery by chloroform extraction}

Solvent extraction is the most extensively adopted method to recover PHA from the cell biomass. In this study, PHA granuals were extracted by using methods described by Santhanam and Sasidharan (2010) as follows: The PHA was directly extracted using chloroform. First, the bacterial cultures were harvested by centrifugation at $5000 \mathrm{rpm}$ for 10 min. The lipids were removed from the cell pellet-using methanol (40 times the volume of cell pellets) and the cells were incubated at $95^{\circ} \mathrm{C}$ for $1 \mathrm{~h}$. before filtered to remove the methanol completely and the sediment granules were incubated in an oven at $65^{\circ} \mathrm{C}$ till dry. Chloroform was added to the dried granules and was incubated at $95^{\circ} \mathrm{C}$ for $10 \mathrm{~min}$ and after cooling, the mixture was gently mixed overnight. The solution was then filtered to get the debris. Finally, the PHA was precipitated from the debris with 7:3 (v/v) mixtures of methanol and water. The precipitated PHA was then washed with acetone and dried.

\section{Recovery by Sodium hypochlorite}

According to the method of Lillo and Valera, (1990), $5 \mathrm{ml}$ of sodium hybochlorite $(12 \%)$ was added to about $0.2 \mathrm{~g}$ of lyophilized cell biomass, and the mixture was leaved at $40^{\circ} \mathrm{C}$ for $1 \mathrm{~h}$. The PHA granules were collected by centrifugation $(2000 \mathrm{xg})$, and the pellet was then washed by water then by ethanol and acetone, and the final pellet was dissolved in chloroform, while the insoluble residue was discarded. The chloroform was evaporated at room temperature and the PHA granules were collected and weighed.

\section{Recovery by $\mathrm{NaOH}$}

PHA was extracted from bacterial cells by using the method of (Choi and Lee, 1998) as follows, cells were treatment in $0.1 \mathrm{M}$ sodium hydroxide $(\mathrm{NaOH})$ and incubated for 1 hour at $30^{\circ} \mathrm{C}$. Every 15 minutes, each tube was vortex for approximately 3 minutes. PHA was separated from the aqueous fraction containing cell debris by centrifugation. Then, the pellet was washed using $20 \%$ ethanol for 3 hours and rinse with distilled water. After centrifugation, the polymers were then kept and dry in freeze-dryer.

\section{Infra Red (IR) spectroscopic analysis of PHA}

The extracted PHA was analyzed for identification of its functional groups through FTIR analysis. The solid samples (PHA) were dissolved in chloroform $\left(\mathrm{CHCl}_{3}\right)$ and deposited as a film on a $\mathrm{KBr}$ disk. The PHA samples analyzed using Fourier Transform Infra Red Spectroscopy, (Model: FTIR-4100 JASCO). The peaks were observed from 4000-400 cm-1 (Ravenelle and Marchessault, 2002). 


\section{RESULTS AND DISCUSSION}

This study has been designed to isolate PHA accumulating bacteria from ecosystem resources and select the more efficient strains with the optimal condition of growth.

\section{Screening of culture collection for PHAs producers}

The bacterial isolates were screened for estimation of the presence of PHAs by using Nile- red assay. The results indicated that two bacterial isolates are of strong fluorescence when stained with Nile-red, therefore they recorded as PHA positives.

Zuriani et al. (2013) used Nile red fluorescence as a rapid quantitative measurement of accumulated polyhydroxyalkanoate (PHA) by microorganisms. Likewise, Landazuri and Maldonado, (2008) reported that various microorganisms isolated from the soil were screened for their PHA production and confirmed by the orange fluorescence emitted after staining with Nile blue dye under UV transilluminator. On the other hands, Juan et al. (1998) used the method of Sudan Black B stain and he considered black stained isolate positives for PHA production and the poorly stained a negative result.

\section{Extraction of PHAs from bacterial cells}

To extract the PHAs, various extraction methods either chloroform, sodium hypochlorite or sodium hydroxide were performed. The results presented in Fig. (1) indicated that the extraction of PHA using chloroform gave $6 \mathrm{mg} / \mathrm{ml}$ with recovery percentage $30 \%$ and sodium hypochlorite extraction give $10 \mathrm{mg} / \mathrm{ml}$ with recovery $50 \%$ but the extraction with $\mathrm{NaOH}$ made the highest value represent $14 \mathrm{mg} / \mathrm{ml}$ with recovery equal $70 \%$. Also, the chloroform extraction method is time consuming and yielded low quantity than the other methods of extraction. On the other hand, the use of $\mathrm{NaOH}$ gave the best results than the chloroform and sodium hypochlorite. It gives the highest value of recovery of PHA than the two other methods of extraction. Similar results were observed by Kunasundari and Sudesh (2011) they extracted PHA with solvents such as chloroform and 1,2-dichloroethane and reported that this method of extraction has some disadvantage as consumption of large volume of toxic and volatile solvents and it is high capital and operation cost. On the other hand, Xuan Jiang (2010) stated that treated biomass with $0.20 \mathrm{~N}$ $\mathrm{NaOH}$ at $22 \pm 1{ }^{\circ} \mathrm{C}$, PHA increased purity to $89.3 \%$.

\section{FTIR spectroscopic analysis}

The FTIR spectroscopic analysis gave further insights into the chemical structure without a previous hydrolysis of the polymer and reflects the existence of monomeric units. As shown in Fig. (2), the results of NG-II isolate indicate the absorption bands appeared in the spectrum are associated with the side chains from the ester $\mathrm{C}=\mathrm{O}$ stretching vibration at $1740 \mathrm{~cm}^{-1}$, the $\mathrm{CH}_{3}$-deformation peak at $1286 \mathrm{~cm}^{-1}$ and the ester $\mathrm{C}-\mathrm{O}-\mathrm{C}$ at $1056 \mathrm{~cm}-1$ which clearly put the extracted polymer sample obtained from isolate in the class of Polyhydroxybutyric acid. The results reported by Hong et al. (1999) indicated that a band at between $1728 \mathrm{~cm}^{-1}$ and $1744 \mathrm{~cm}^{-1}$ is characteristic for PHA. Our results agree with results reported by Jarute et al. 2004) and Kansiz et al., (2007) who clearly indicated that this spectrum is associated with the presence of PHB in pure cultures at about $1730 \mathrm{~cm}-1$.

\section{Optimization of the cultivation conditions}

\section{Effect of different fermentation media on Cell growth}

To achieve enough biomass from NG-II isolate required as inoculum for PHB production, various growth media (YT, LB and SG), and incubation times (24, 48 and $72 \mathrm{hr}$ ) 
at $30^{\circ} \mathrm{C}$ were studied. As shown in Fig. (3) After incubation time for 72 hours, YT medium yielded the highest cell biomass to be used in the further studies. Our results agree with results of Khanafari et al. (2006) he reported that poly- $\beta$ hydroxyl-butyrate production was increased in presence of meat extract up to $75 \%$ of the cell dry weight after $48 \mathrm{~h}$. At same time, the addition of nitrogenous source had a positive effect on poly- $\beta$ hydroxyl-butyrate production and presence of meat extract made $4.43 \mathrm{~g} / \mathrm{L}$ of PHB yields.

\section{The effect of hydrogen ion concentration (pH)}

In this experiment, the optimized mineral salt medium was prepared as previously described and the medium was initially adjusted at different $\mathrm{pH}$ values ranged from 6.0 to 8.5 using either $\mathrm{NaOH}(1 \mathrm{~N})$ or $\mathrm{HCl}(1 \mathrm{~N})$. Under the optimized growth conditions (incubation at $37^{\circ} \mathrm{C}$ for 48 hour in $\mathrm{HM}$ medium), the effect of $\mathrm{pH}$ on the growth rate of NGII isolate was examined. As shown in Fig. (4), the results cleared that the highest growth rate (O.D $600=0.85$ ) was observed at $\mathrm{pH} 7.2$, a significant decrease in PHB accumulation was observed when the culture grew at lower or higher $\mathrm{pH}$ values. Our results seemed to be the same results of Sreya et al. (2012) who reported an optimum growth of isolate VK-12 of genus Burkholderia $\mathrm{pH} 7.0$, temperature $30{ }^{\circ} \mathrm{C}$ and incubation time at $48 \mathrm{~h}$.

\section{Effect of different carbon sources on the production of PHB}

Under the optimized growth conditions, different carbon sources were tested. The data presented in Fig. (5) showed that the highest PHB yield was recorded with glucose $(0.5$ $\mathrm{mg} / \mathrm{ml})$, Sucrose $(4 \mathrm{mg} / \mathrm{ml})$, peptone $(2 \mathrm{mg} / \mathrm{ml})$, yeast extract $(1 \mathrm{mg} / \mathrm{ml})$, and starch $(1.5$ $\mathrm{mg} / \mathrm{ml})$, However, the highest PHB yield among all the tested carbon sources was observed with sucrose $(4 \mathrm{mg} / \mathrm{ml})$.

\section{PHB production from date palm syrup as inexpensive Carbone source}

The effect of different concentrations of date palm syrup (1-30\% v/v) as inexpensive carbon source was studied. In HM medium with incubation time for $48 \mathrm{~h}$ at $37^{\circ} \mathrm{C}$, different date palm syrup concentrations ranged from 1 to $30 \%$ (v/v) were tested. The data revealed that the highest amount of PHB $(4.5 \mathrm{mg} / \mathrm{ml})$ produced by the NG-II isolate was achieved with date palm syrup (Khalas) concentration of $8 \%$ as illustrated in Fig (6). Our results closely agree with the results reported by Omar et al. (2001) who found that optimal growth and PHB accumulation in Bacillus megaterium occurred with $5 \%(\mathrm{w} / \mathrm{v})$ date syrup.

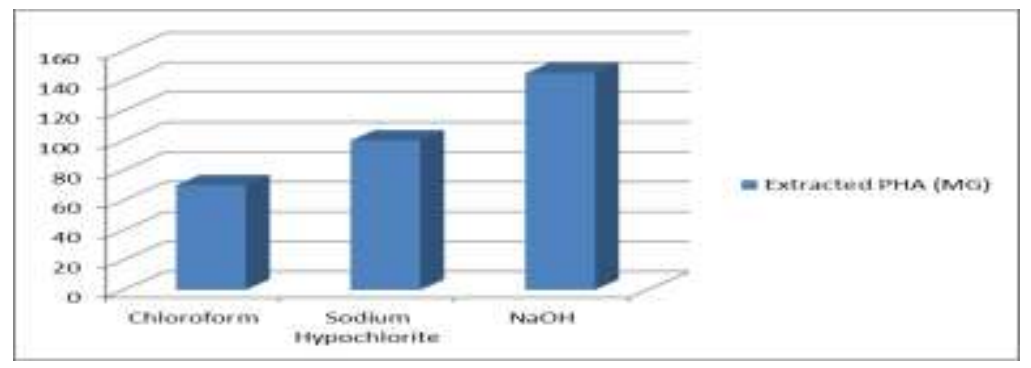

Fig. (1): PHA yields extracted with different extraction methods. 


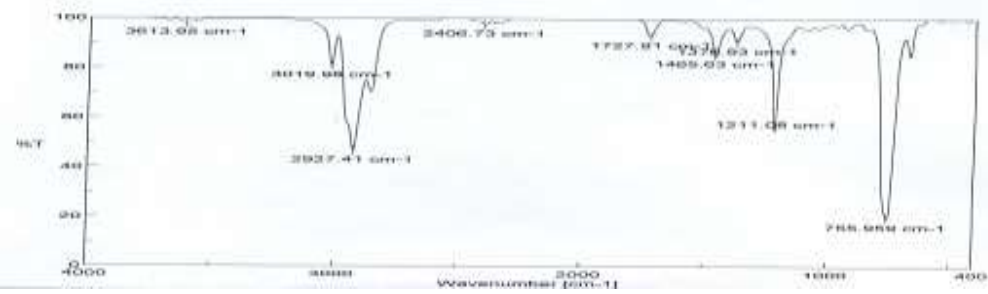

Fig 2: IR spectrum of extracted biopolymer

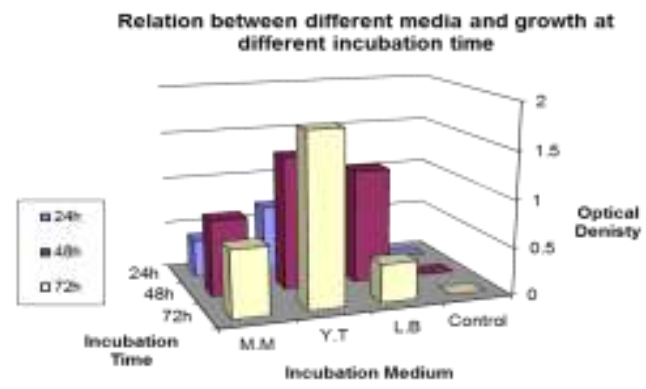

Fig 3: Effect of different nutrient media and different incubation times.

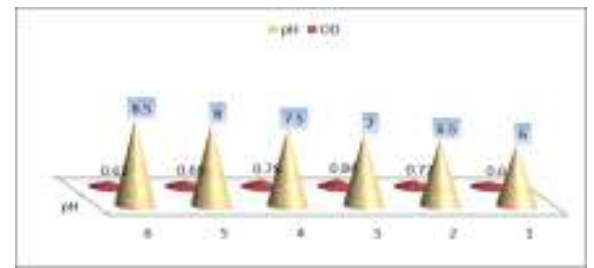

Fig 4: The effect of different $\mathrm{pH}$ values on bacterial growth.

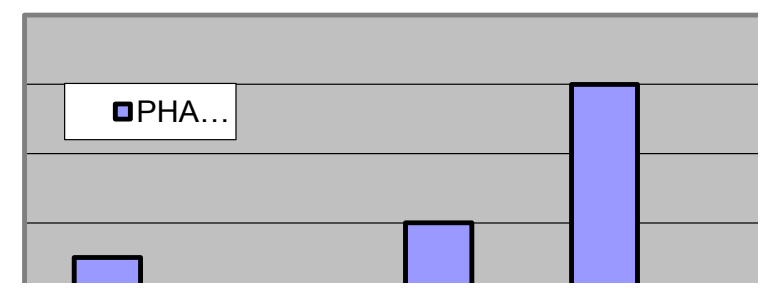

Fig 5: 'The eftect of difterent carbon sources on PHA content.

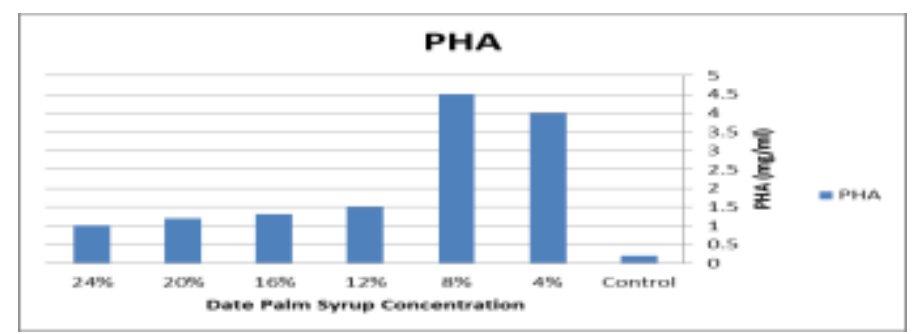

Fig 6: Effect of different Date Palm syrup concentrations 


\section{ACKNOWLEDGEMENTS}

This project was supported by grant No. 36/H/1432. Deanship of Scientific Research, Salman Bin Abdullaziz University, Al-Kharj, KSA.

\section{REFRENCES}

Ahn, W. S., S. J. Park, and S. Y. Lee. (2000): Production of poly(3-hydroxybutyrate) by fed-batch culture of recombinant Escherichia coli with a highly concentrated whey solution. Appl. Environ. Microbiol. 66:3624-3627.

Anderson AJ, Dawes EA (1990): Occurrence, metabolism, metabolic role, and industrial uses of bacterial polyhydroxyalkanoates. Microbiol Rev 54:450-472

Choi, J., Lee, S.Y., (1998): Isolation of poly-3-hydroxybutyrate [P(3HB)] accumulating bacteria from soil and production of $\mathrm{P}(3 \mathrm{HB})$ from inexpensive carbon substrates, Annual Meeting of Korean Society for Applied Microbiology, Korea Univ., April.

Christopher J. Brigham and Anthony J. Sinskey (2012): Applications of Polyhydroxyalkanoates in the Medical Industry. International Journal of Biotechnology for Wellness Industries, 1, 53-60.

Gulab Singh, Arpana Mittal, Anish Kumari, Varsha Goel, Neeraj K Aggarwal and Anita Yadav (2011): Optimization of Poly-B-Hydroxybutyrate Production from Bacillus species. European Journal of Biological Sciences 3 (4): 112-116.

Hanahan, D. (1985): Techniques for transformation of E. coli. In DNA cloning: A Practical Approach (ed. D.M. Glover), vol. 1 pp. 109-135. IRL Press, Oxford, United Kingdom.

Jarute, G., Kainz, A., Schroll, G., Baena, J.R., Lendl, B., (2004): On-line determination of the intracellular poly ( $\beta$-hydroxybutyric acid) content in transformed Escherichia coli and glucose during PHB production using stopped-flow attenuated total reflection FT-IR spectrometry. Anal. Chem. 76, 6353-6358.

Kansiz, M., Domínguez-Vidal, A., McNaughton, D., Lendl, B., (2007): Fourier-transform infrared (FTIR) spectroscopy for monitoring and determining the degree of crystallisation of polyhydroxyalkanoates (PHAs). Anal. Bioanal. Chem. 388, 1207-1213.

Khanafari A., Akhavan A. Sepahei and Mogharab M. (2006): Production and recovery of poly- $\beta$ hydroxybutyrate from whey degradation by Azotobacter . Iran. J. Environ. Health. Sci. Eng., 2006, Vol. 3, No. 3, pp. 193-198

Kim, B. S. Lee, S. C. Lee, S. Y. Chang, H. N. Chang Y. K. and Woo, S. I. (1994): "Production of poly(3-hydroxybutyric acid) by fed-batch culture of Alcaligenes eutrophus with glucose concentration control," Biotechnology and Bioengineering, vol. 43, No.9, pp. 892-898.

Kunasundari B., Sudesh K. (2011): Isolation and recovery of microbial polyhydroxyalkanoates. eXPRESS Polymer Letters Vol.5, No.7 , 620-634. 
Lee, S.Y. (1996): Bacterial polyhydroxyalkanoates. Biotechnol Bioeng 49, 1-14.

Lillo, J. G. and Valera F. $R$ (1990): Effects of Culture Conditions on Poly(3Hydroxybutyric Acid) Production by Haloferax Mediterranei. Applied and Environmental, p. 2517-2521.

Madison, L.L. \& Huisman, G.W. (1999): Metabolic Engineering of Poly(3Hydroxyalkanoates): From DNA to Plastic. Microbiology and Molecular Biology Reviews, Vol. 63, No. 1, pp. 21-53.

Mahishi, L.H., Tripathi, G. and Rawal, S.K. (2003): Poly(3-hydroxybutyrate) (PHB) synthesis by recombinant Escherichia coli harbouring Streptomyces aureofaciens PHB biosynthesis genes: Effect of various carbon and nitrogen sources. Microbiol Res 158, 19-27.

Omar S, Rayes A, Eqaab A, Voß I, Steinbuchel A (2001): Optimization of cell growth and poly(3-hydroxybutyrate) accumulation on date syrup by a Bacillus megaterium strain. Biotechnology Letters;23:1119-1123.

Page, W.J. (1992): Production of polyhydroxyalkanoates by Azotobacter vinelandii UWD in beet molasses culture. FEMS Microbiol. Rev. 103, 149-158.

Quillaguamán, J., Hatti-Kaul, R., Mattiasson, B.,Alvarez, M.T., and Delgado, O. (2004): Halomonas boliviensis sp. nov., an alkalitolerant, moderate halophile bacterium isolated from soil around a Bolivian hypersaline lake. Int. J. Syst. Evol. Microbiol. 54: 721-725

Ramsay, J.A., Berger, E., Ramsay, B.A. and Chavarie, C. (1990): Recovery of poly-3hydroxyalkanoic acid granules by a surfactant-hypochlorite treatment. Biotechnol Tech 4, 221- 226.

Ravenelle, F. and Marchessault. R. H., (2002): "One-step synthesis of amphiphilic diblock copolymers from bacterial poly ([R]-3-hydroxybutyric acid)," Biomacromolecules, No. 3, pp. 1057-1064.

Santhanam and Sasidharan S. (2010): Microbial production of polyhydroxyalkanotes (PHA) from Alcaligens spp. and Pseudomonas oleovorans using different carbon sources. In African Journal of Biotechnology, Vol. 9, p. 3144-3150.

Sreya, K.; Prabhat, K.S. and Ambarish S V. (2012): Screening of root nodule bacteria for the production of polyhydroxyalkanoate (PHA) and the study of parameters influencing the PHA accumulation. African Journal of Biotechnology Vol. 11(31), pp. 7934-7946.

Xuan Jiang (2010): process development for the production and separation of medium chain length poly (3-hydroxyalkonates) by pseudomonas putida KT2440. A thesis submitted to the Department of Chemical Engineering In conformity with the requirements for the degree of Doctor of Philosophy.

Zuriani R., Vigneswari S., Azizan M. N, Majid I. A. and Amirul A. A (2013): A high throughput Nile red fluorescence method for rapid quantification of intracellular bacterial polyhydroxyalkanoates. Biotechnology and Bioprocess Engineering, Volume 18, Issue 3, pp 472-478 


\title{
انتاج البوليمر البيولوجي هيدروكسي بيوترات (PHB) من مخلفات الصناعة
}

\author{
جمال جبر و نهلة حسان \\ قسم الصيدلة. كلية الصيدلة. جامعة سلمان بن عبد العزيز. السعودية. \\ و معهل بحوث تكنولوجيا الاغذية. مصر.
}

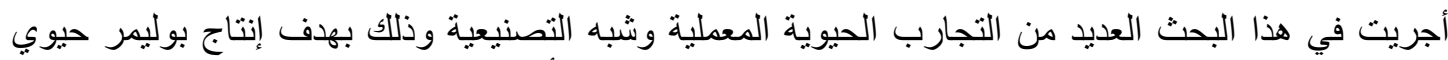
ذو خاصية تحلليه حيوية (Biopolymer)

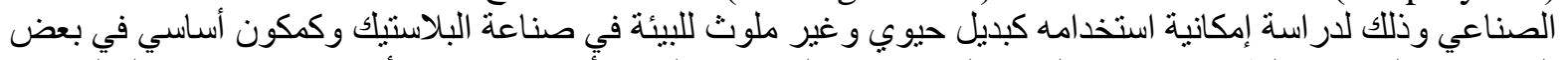

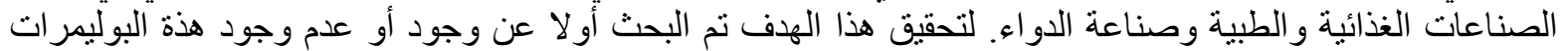

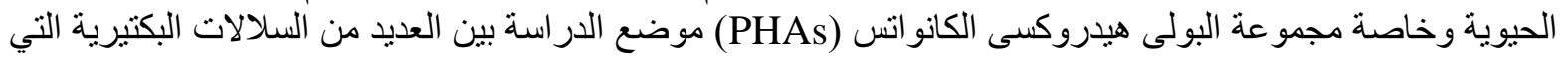

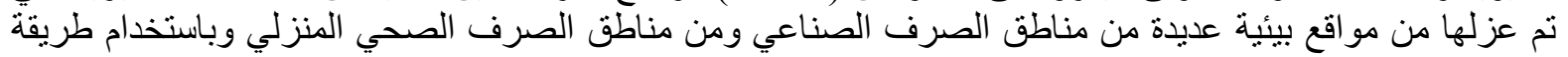

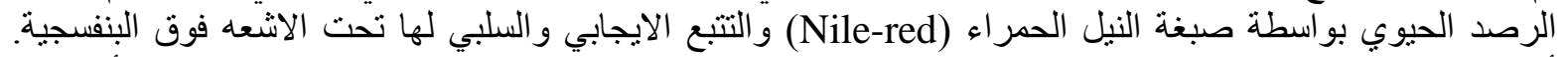

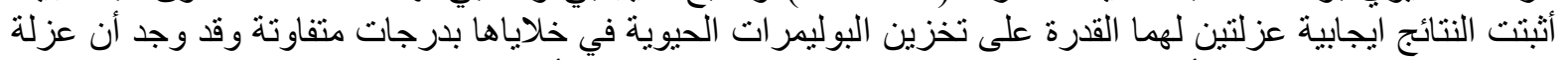

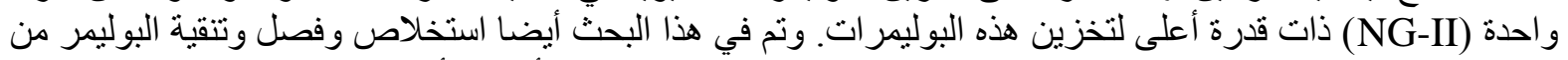

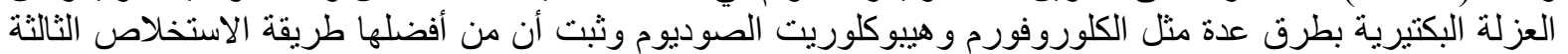

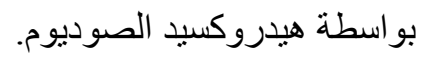

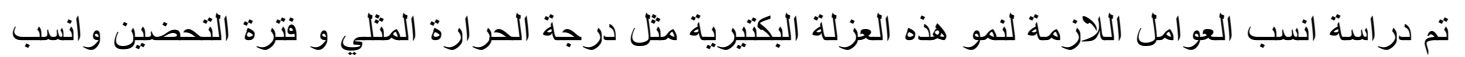

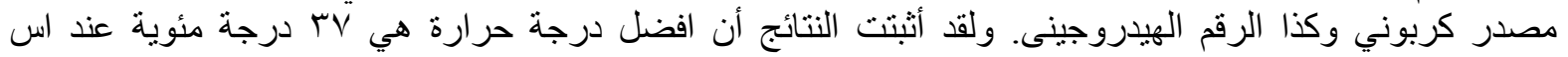

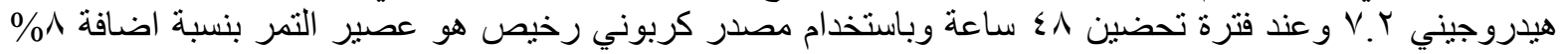
الى الوسط الغذائي.

الدرسات مستمرة لاستغلال هذا المركب العديد في مجال الصيدلة و التغذية و فقا لتكنولوجيا النانو. 